\title{
Systemic Administration of Thrombin Peptide TP508 Enhances VEGF-Stimulated Angiogenesis and Attenuates Effects of Chronic Hypoxia
}

\author{
Barbara Olszewska-Pazdrak ${ }^{a, b}$ Darrell H. Carney ${ }^{a, b}$

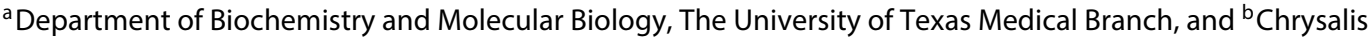 \\ BioTherapeutics Inc., Galveston, Tex., USA
}

\section{Key Words}

Therapeutic angiogenesis · Vascular endothelial growth factor $\cdot$ Thrombin peptide $\cdot$ Rusalatide acetate . Endothelial dysfunction · Hypoxia · Endothelial cells

\begin{abstract}
Revascularization of chronic wounds and ischemic tissue is attenuated by endothelial dysfunction and the inability of angiogenic factors to stimulate angiogenesis. We recently showed that TP508, a nonproteolytic thrombin peptide, increases perfusion and NO-dependent vasodilation in hearts with chronic ischemia and stimulates NO production by endothelial cells. In this study, we investigated systemic in vivo effects of TP508 on VEGF-stimulated angiogenesis in vitro using aortic explants in normoxic and hypoxic conditions. Mice were injected with saline or TP508 and $24 \mathrm{~h}$ later aortas were removed and cultured to quantify endothelial sprouting. TP508 injection increased endothelial sprouting and potentiated the in vitro response to VEGF. Exposure of control explants to hypoxia inhibited basal and VEGF-stimulated endothelial cell sprouting. This effect of hypoxia was significantly prevented by TP508 injection. Thus, TP508 systemic administration increases responsiveness of aortic endothelial cells to VEGF and diminishes the effect of chronic hypoxia on endothelial cell sprouting. Studies using human endo-
\end{abstract}

thelial cells in culture suggest that protective effects of TP508 during hypoxia may involve stimulation of endothelial cell NO production. These data suggest potential clinical benefit of using a combination of systemic TP508 and local VEGF as a therapy for revascularization of ischemic tissue.

Copyright $\odot 2013$ S. Karger AG, Basel

\section{Introduction}

TP508 is a 23 amino acid synthetic peptide representing residues $508-530$ of human prothrombin which was identified as a potential receptor-binding domain based on competition for high-affinity thrombin binding to fibroblasts [1]. In contrast to thrombin, TP508 has no enzymatic activity and does not promote or interfere with blood coagulation [1]. Studies have shown that TP508 accelerates healing of dermal wounds [2-4], fractures [5] and bone defects $[6,7]$. TP508 is being evaluated in human clinical trials as a therapeutic drug for treatment of diabetic foot ulcers [8] and for acceleration of fracture

The authors disclose that D.H.C. owns stock in Chrysalis BioTherapeutics Inc. and that B.O.-P. receives financial support from Chrysalis BioTherapeutics Inc. Potential conflicts of interest are managed by The University of Texas Medical Branch Conflict of Interests Committee.

\section{KARGER}

E-Mail karger@karger.com

www.karger.com/jvr
(C) 2013 S. Karger AG, Basel

$1018-1172 / 13 / 0503-0186 \$ 38.00 / 0$
Prof. Darrell H. Carney

Department of Biochemistry and Molecular Biology

The University of Texas Medical Branch

301 University Blvd., Galveston, TX 77555-0645 (USA)

E-Mail dcarney@utmb.edu 
repair [9]. TP508 acceleration of healing is associated with stimulation of early revascularization in dermal and bone injury models $[2,3,5,10]$. From these studies, however, it is not clear whether TP508 stimulated angiogenesis by itself or promoted angiogenic responses to other factors present in the injured tissue.

VEGF is an important angiogenesis factor that is produced by hypoxic cells during tissue injury to stimulate and direct angiogenesis [11, 12]. A number of studies have shown that VEGF-stimulated endothelial angiogenic responses in vitro [13-17] and angiogenesis in vivo $[18,19]$ require activation of endothelial nitric oxide synthase (eNOS). Although VEGF administration increases revascularization of ischemic tissue in experimental animal models, only limited benefit was achieved with VEGF therapeutic angiogenesis in clinical trials in patients with myocardial ischemia [20-22]. Thus, this limited effect of VEGF in patients with coronary artery disease suggests decreased endothelial cell responsiveness to VEGF in chronically hypoxic tissues. We have shown that exposure of human endothelial cells to chronic hypoxia attenuates VEGF-stimulated signaling and angiogenic responses [23]. We recently demonstrated that TP508 activates eNOS and stimulates production of NO in human endothelial cells [23]. Using a pig model of chronic myocardial ischemia, we demonstrated that TP508 increased myocardial perfusion and function, and restored NO-dependent vasodilatation and NO production in arterioles isolated from ischemic myocardial regions [24]. More recently, it has been shown that TP508 decreased infarct size, improved NOdependent microvascular function and increased activation of eNOS following acute myocardial ischemia-reperfusion injury in normal [25], hypercholesterolemic [26] and diabetic pigs [27]. These studies led us to hypothesize that TP508 protects endothelial cells from hypoxia-induced loss of endothelial function, and potentiates responsiveness of vascular endothelial cells to VEGF.

The purpose of this study was to examine systemic effects of TP508 on VEGF-stimulated angiogenesis in vitro using aortic explants and to determine whether TP508 administrated in vivo protects endothelial cells against effects of chronic hypoxia. Our results demonstrate that TP508 intravenous injection increases endothelial cell sprouting and enhances VEGF-stimulated sprouting from aortic explants isolated from mice $24 \mathrm{~h}$ after injection. Moreover, chronic hypoxia markedly inhibits basal and VEGF-induced endothelial cell sprouting, but TP508 injection protects endothelial cells from this hypoxic effect. These results suggest potential therapeutic benefit of a combination of VEGF and TP508 for myocardial revascularization or treatment of peripheral artery disease.

\section{Materials and Methods}

\section{Reagents}

Thrombin peptide TP508 (AGYKPDEGKRGDACEGDSGGPFV, also known as rusalatide acetate CAS No. 87455-82-6) was synthesized and purified by American Peptide Company (Sunnyvale, Calif., USA). Human recombinant VEGFA165 was purchased from R\&D systems (Minneapolis, Minn., USA). Matrigel Matrix (phenol red free) was obtained from (BD Biosciences, Bedford, Mass., USA). L-arginine, $\mathrm{NaNO}_{2}$, and $\mathrm{NaI}$ were purchased from Sigma (St Louis, Mo., USA).

\section{Animals}

All experiments were approved by the UTMB Institutional Animal Care and Use Committee. Twelve- to 15-week-old ICR male mice (Charles River Laboratories, Wilmington Mass., USA) were housed ( 5 per cage) in a controlled environment with a 12 hour light/dark cycle, with temperature maintained at $21 \pm 0.5^{\circ} \mathrm{C}$ and a room humidity of $50 \pm 20 \%$. Water and chow were provided ad libitum. Mice were placed in a restrainer and their tail veins were injected with a single $500-\mu \mathrm{g}$ dose of TP508 in $100 \mu \mathrm{l}$ of saline or with $100 \mu \mathrm{l}$ of saline alone (placebo control). A single injection of TP508 (500 $\mu \mathrm{g} /$ mouse) was chosen for these studies based on dose response studies of TP508 injection on ex vivo aortic endothelial cell sprouting and in vivo biological effects where injection of $500 \mu \mathrm{g} /$ mouse showed maximal effects [manuscript in preparation]. After $24 \mathrm{~h}$ mice were euthanized by $\mathrm{CO}_{2}$ inhalation and aortas were removed as previously described [28, 29].

\section{Mouse Aortic Explant Angiogenesis Assay}

Angiogenic endothelial cell sprouting was studied by culturing mouse aortic explants on Matrigel Matrix (BD Biosciences) as described previously $[28,29]$. Twenty-four hours postinjection, thoracic aortas were isolated from TP508- or saline-administrated mice and transferred to culture dishes containing cold endothelial basal medium (EBM; Lonza, Walkersville, Md., USA). The periaortic fibroadipose tissue was removed under a dissecting microscope and aortas were rinsed with cold EBM and cut transversely to create $1 \mathrm{~mm}$ aortic rings ( $\sim 10$ per aorta). Aortic rings were cut, opened and the inner endothelial surface was placed directly on Matrigel Matrix coated wells of 24-well plates. Aortic explants were cultured in endothelial growth medium which contains EBM supplemented with $5 \%$ fetal bovine serum and SingleQuots (Lonza) in $5 \% \mathrm{CO}_{2}$ at $37^{\circ} \mathrm{C}$. After $24 \mathrm{~h}$ of culture, aortic explants from control or TP508-injected mice were stimulated with VEGF $(50 \mathrm{ng} / \mathrm{ml})$ or vehicle and cultured in normoxia. To determine the effects of hypoxia, aortic explants from control and TP508-injected mice were incubated with or without VEGF under hypoxic conditions $\left(1 \% \mathrm{O}_{2}, 5 \% \mathrm{CO}_{2}\right)$ for 2 days and then switched back to normoxia. Endothelial cell sprouting was monitored daily by inverted phase-contrast microscopy (Nikon, Tokyo, Japan) and images were captured using a Spot RT camera 
with Spot Advance image capture software (Diagnostic Instruments Inc., Sterling Heights, Mich., USA) at $\times 40$ and $\times 100$ magnification.

\section{Quantification of Endothelial Sprouting}

Image analysis and quantification for the area occupied by sprouting endothelial cells and maximal endothelial cell migration from aortic explants edges was performed using MetaMorph software (Molecular Devices, Downingtown, Pa., USA). For each experiment, we isolated aortas from three controls and from three TP508-injected mice. Aortic sprouting was quantified from triplicate culture wells containing a total of 6 aortic explants per experimental condition. The area of endothelial sprouting was normalized to the perimeter of aortic explants visualized in the field of observation. The area of sprouting from control mouse explants cultured in normoxia for 5 days was expressed as a value of 1.0. For maximum endothelial cell migration we measured the longest distance of migrated cells from the edges of aortic explants in 3 different regions from each explant.

\section{Endothelial Cell Culture}

Human coronary artery endothelial (HCAE) cells from Lonza were cultured in endothelial growth medium (EBM supplemented with $5 \%$ FBS and SingleQuots; Lonza) in $5 \% \mathrm{CO}_{2}$ at $37^{\circ} \mathrm{C}$. Two-day postconfluent HCAE cells, between passages 4 and 6 , were cultured in normoxic or hypoxic $\left(1 \% \mathrm{O}_{2}, 5 \% \mathrm{CO}_{2}\right.$ at $\left.37^{\circ} \mathrm{C}\right)$ conditions and assayed for effects of hypoxia on VEGF expression, viability and NO production.

\section{Real-Time PCR}

Quantitative SYBR Green real-time PCR was used to determine the expression of human VEGF mRNA. HCAE cells were cultured on 6-well plates. Two-day postconfluent cells were treated with TP508 $(50 \mu \mathrm{g} / \mathrm{ml})$ or vehicle and cultured in normoxic or hypoxic conditions for $24 \mathrm{~h}$. Total RNA was isolated using RNAqueous kits (Ambion, Austin, Tex., USA). Isolated mRNA samples were coded for blinded analysis. Total RNA was reverse transcribed using Taqman Reverse Transcription Reagents Kits (ABI). Quantitative PCR amplifications were done using $2 \mu \mathrm{l}$ of $\mathrm{cDNA}$ in a total volume of $25 \mu \mathrm{l}$ using SYBR Green PCR Master Mix (ABI) on an ABI Prism 7000 Sequence Detection System. Primers for human VEGFA were sense: TAC CTC CAC CAT GCC AAG TG and antisense: GCG CTG ATA GAC ATC CAT GAA C. These primers recognize common sequence for all splice variant transcripts of human VEGFA. Reverse-transcribed cDNA cycle threshold values were calculated from triplicate sample determinations and normalized to $18 \mathrm{~S}$ RNA.

NO Assay

Confluent HCAE cells were cultured on 24-well plates under normoxic or hypoxic conditions for $24 \mathrm{~h}$. Normoxic and hypoxic cells were then stimulated with TP508 $(50 \mu \mathrm{g} / \mathrm{ml})$ or VEGF $(50 \mathrm{ng} / \mathrm{ml})$ or vehicle (control) in the same conditions. After $24 \mathrm{~h}$ of stimulation, the medium was replaced with EBM containing $200 \mu \mathrm{M} \mathrm{L}$-arginine $(250 \mu \mathrm{l} /$ well $)$ and all cells were assayed for NO production during $1 \mathrm{~h}$ normoxic incubation. Supernatants were collected and analyzed for NO concentrations using a chemiluminescence NO analyzer (Model 270B, Sievers Instruments, Boulder, Colo., USA) as previously described [30]. The analyzer was calibrated for each experiment using a sodium nitrite stan- dard curve. NO concentration in the EBM containing L-arginine was used as a background value and was subtracted from sample values to determine the amount of NO released from cells.

Statistical Analysis

Analysis of variance (ANOVA) was used to determine if there was a significant difference among groups. A pair-wise comparison of groups was then done using the Tukey test. $\mathrm{p}<0.05$ was regarded as significant.

\section{Results}

\section{TP508 Systemic Injection Increases Endothelial}

Sprouting from Aortic Explants

Stimulation of angiogenesis leading to tissue revascularization is required for normal wound healing after injury or surgical procedures [31]. The aortic sprouting assay is a well-established model for studying the effects of different factors on angiogenesis in vitro [28, 29]. We used this model to determine the systemic effects of TP508 administered in vivo on angiogenic endothelial cell functions. Aortic explants were isolated from mice $24 \mathrm{~h}$ after TP508 or saline injection and cultured on Matrigel Matrix. As shown in figure 1a, endothelial cell sprouting was observed in aortic explants from control and TP508-injected mice after 4 days in culture. Explants from TP508-injected mice showed greater sprouting than controls at day 4 (fig. 1a). These sprouting endothelial cells grew progressively to form a branching network by day 5 characteristic of endothelial cells cultured on Matrigel (fig. 1a). Morphometric analysis of the area occupied by endothelial cells and maximal endothelial cell migration was significantly greater in aortic explants isolated from TP508-injected mice than in control explants on days 4, 5 and 6 (fig. 1b). For example, TP508-injected mouse aortic explants had a 6.4-fold increased area and 3.1-fold increased maximal migration of sprouting compared to explants from control mice at day 5 (fig. $3 \mathrm{a}$ ). Thus, a single TP508 intravenous injection increased endothelial sprouting from aortic explants measured several days later.

\section{TP508 Systemic Injection Potentiates VEGF- \\ Stimulated Angiogenesis}

VEGF is a key angiogenesis factor produced during tissue injury to stimulate and direct angiogenesis $[11,12]$. Thus, we examined the effect of in vivo systemic TP508 administration on angiogenesis stimulated by VEGF in vitro using the aortic explants. As expected, VEGF treatment of aortic explants from control mice resulted in in- 


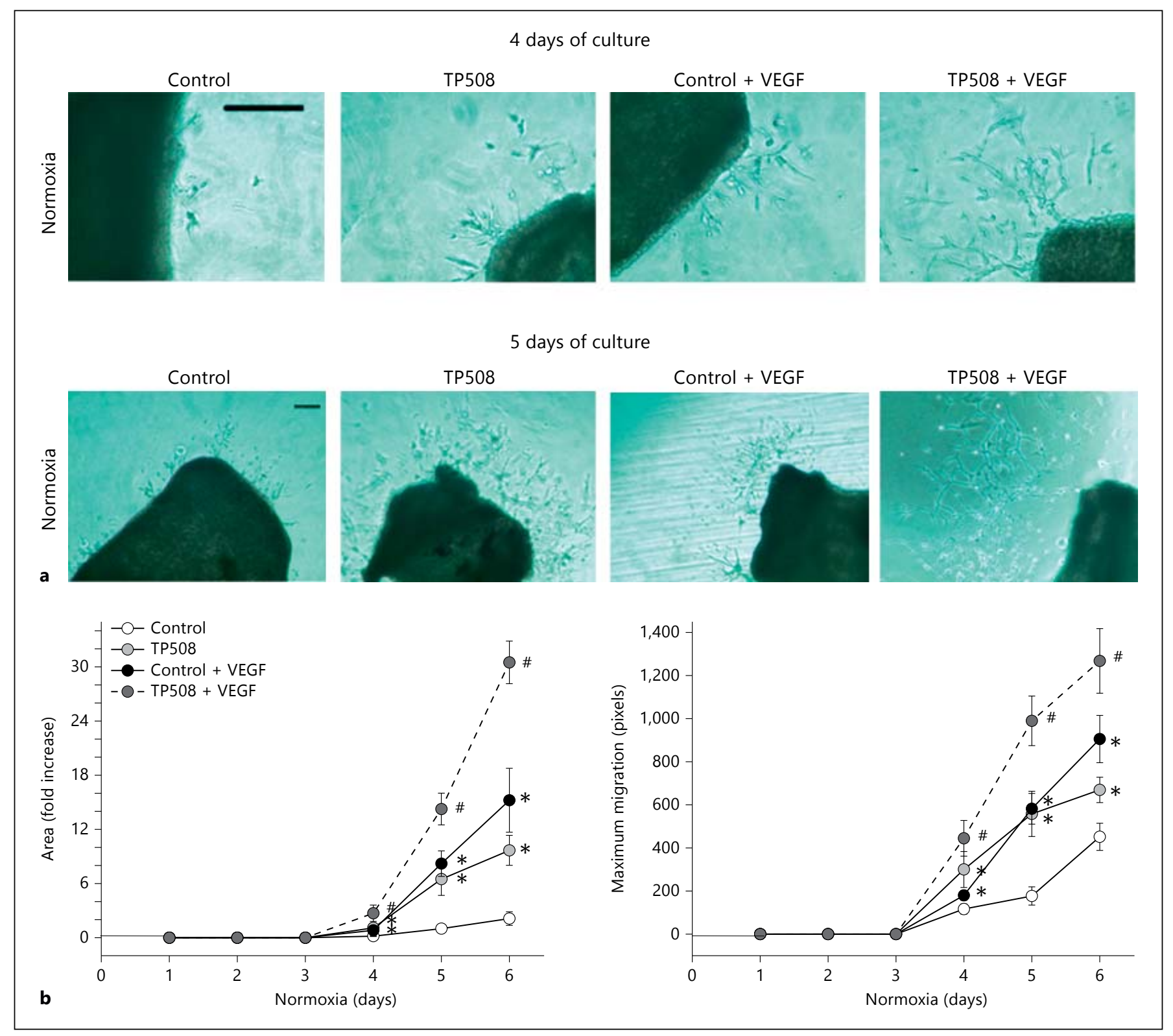

Fig. 1. TP508 injection increases endothelial sprouting and potentiates VEGF-stimulated angiogenesis. Aortas were isolated from mice $24 \mathrm{~h}$ postintravenous injection of saline (control) or TP508 $(500 \mu \mathrm{g} / 100 \mu \mathrm{l})$. Aortic explants were cultured on Matrigel Matrix for 6 days under normoxic conditions in growth medium without or with VEGF (50 ng/ml) and photographed daily. a Representative images of endothelial sprouting from explants after 4 and

creased area and migration of sprouting at all examined days compared to control, untreated explants (fig. 1a, b). We observed an 8.2- and 3.3-fold increased area and migration of sprouting, respectively, after 5 days culture in aortic explants from control mice in response to VEGF (fig. 3a, normoxia). This VEGF-stimulated sprouting
5 days of culture. Four- and 5-day images were taken under $\times 100$ and $\times 40$ magnifications, respectively. Scale bar $=200 \mu \mathrm{m}$. b Digital image quantification of area and maximal migration of cell sprouting from aortic explants (days 1-6). Data are expressed as a mean \pm $\mathrm{SD} ; \mathrm{n}=4,{ }^{*} \mathrm{p}<0.05$ compared to control, ${ }^{*} \mathrm{p}<0.05$ compared to control + VEGF.

from control explants at day 5 was comparable to the sprouting from aortic explants isolated from TP508-injected mice without VEGF stimulation (fig. 3a, normoxia). Importantly, VEGF stimulation of aortic explants isolated from TP508-injected mice showed significantly greater endothelial sprouting compared to aortic sprouting in re- 


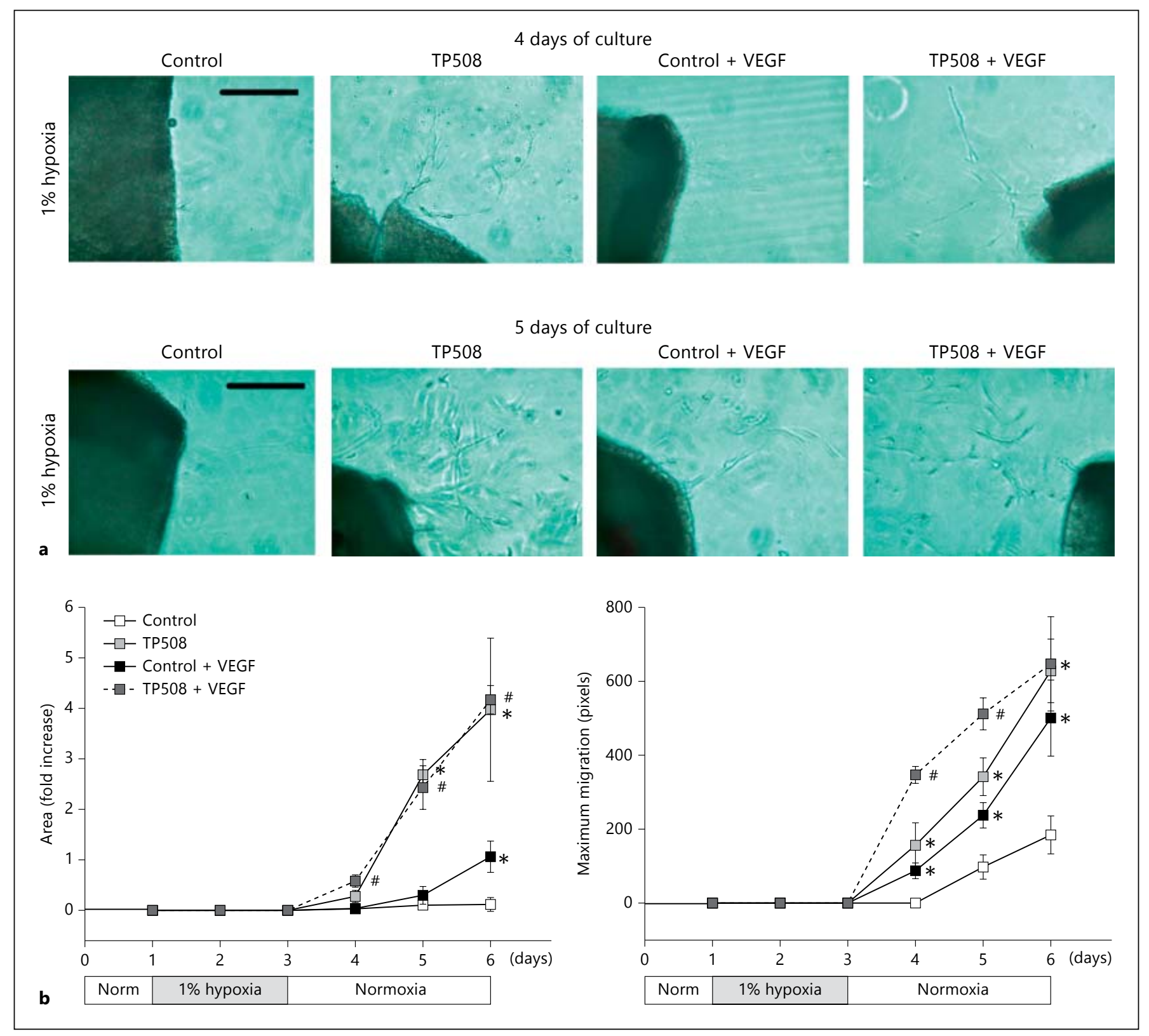

Fig. 2. Effect of chronic hypoxia on endothelial cell sprouting. Aortas were isolated from saline (control) or TP508-injected (500 $\mu \mathrm{g} / 100 \mu \mathrm{l})$ mice and aortic explants were cultured on Matrigel Matrix. Aortic explants from control or TP508-injected mice were stimulated with or without VEGF (50 ng/ml; control + VEGF and TP508 + VEGF, respectively) and exposed to hypoxia $\left(1 \% \mathrm{O}_{2}\right)$ for 2 days and returned to normoxia. a Representative photographs of

sponse to VEGF from control mice on days 4,5 and 6 (fig. 1a, b). These results demonstrate that in addition to promoting endothelial sprouting, TP508 injection also increases responsiveness of endothelial cells from aortic explants to VEGF-stimulated angiogenesis in vitro. cell sprouting from aortic explants after 4 and 5 days of culture are shown (magnification $\times 100$ ). Scale bar $=200 \mu \mathrm{m}$. b Digital image quantification of area and maximal migration of cell sprouting from aortic explants. Data are expressed as a mean $\pm S D ; n=4$, ${ }^{*} \mathrm{p}<0.05$ compared to control, ${ }^{\#} \mathrm{p}<0.05$ compared to control + VEGF.

\section{TP508 Injection Diminished Effects of Hypoxia on Angiogenesis}

We have shown that exposure of human coronary endothelial cells to chronic hypoxia $\left(1 \% \mathrm{O}_{2}\right)$ attenuates endothelial cell angiogenic responses [23]. The aortic angio- 


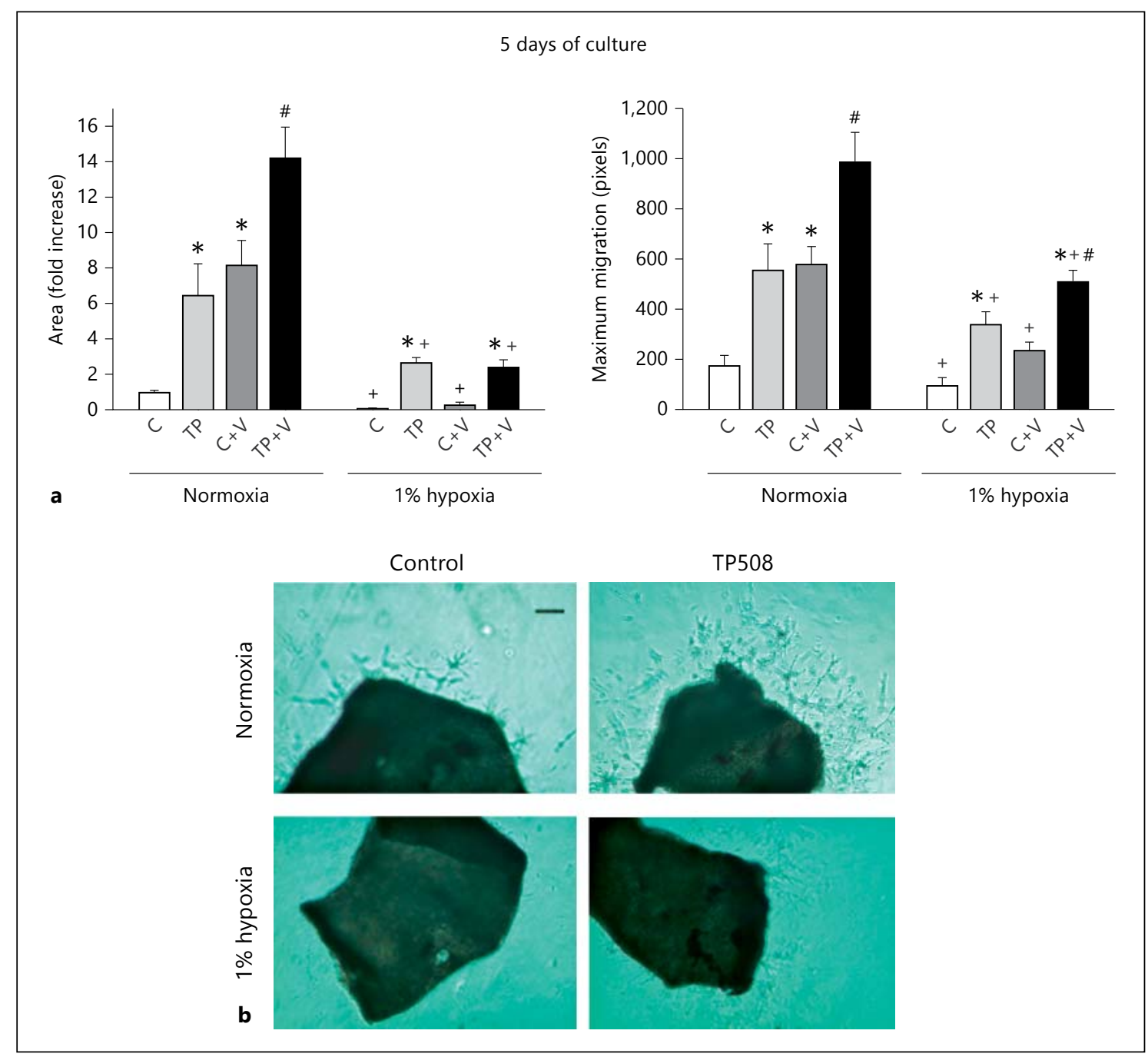

Fig. 3. Comparison of endothelial cell sprouting after 5 days of culture in normoxic and hypoxic conditions. a Area and migration of endothelial sprouting was quantified after 5 days and statistically analyzed for the effect of hypoxic exposure. Data are expressed as mean $\pm \mathrm{SD} ; \mathrm{n}=4$; ${ }^{*} \mathrm{p}<0.05$ compared to control in normoxia, ${ }^{\#} \mathrm{p}<0.05$ compared to control $+\mathrm{VEGF},{ }^{+} \mathrm{p}<0.05$ compared to

genic sprouting assay allows us to evaluate ex vivo effects of hypoxia on angiogenic responses of endothelial cells from intact vessel walls. This model also allows us to determine whether TP508 delivered in vivo can protect endothelial cells against effects of hypoxia.

Aortic explants isolated from control and TP508-injected mice were cultured for $24 \mathrm{~h}$ in normoxia to allow the explants to attach to the Matrigel and then switched to hypoxia $\left(1 \% \mathrm{O}_{2}\right)$. In preliminary experiments we observed that continued culture of aortic explants under hypoxia completely inhibited endothelial sprouting, but if normoxia for each treatment. $\mathrm{C}=$ Control; $\mathrm{TP}=\mathrm{TP} 508 ; \mathrm{V}=\mathrm{VEGF}$. b Effect of TP508-injection on hypoxia-induced attenuation of sprouting. Representative photographs of cell sprouting from aortic explants isolated from control and TP508-treated mice cultured in normoxic or hypoxic conditions for 5 days are shown (magnification $\times 40$ ). Scale bar $=200 \mu \mathrm{m}$. and then returned to normoxia, measurable sprouting was observed. Explant exposure to hypoxia for 2 days markedly decreased the area of sprouting compared to the same explants cultured continuously in normoxia (fig. 2a, b, 3a, b). Moreover, VEGF-stimulated sprouting was suppressed during hypoxic exposure (fig. 2, 3a). At day 5 of culture, the area and maximal migration of endothelial sprouting in VEGF-stimulated control explants exposed to hypoxia was reduced 27- and 2.5-fold, respectively, compared to VEGF-stimulated sprouting in nor- 
moxia (fig. 3a). Hypoxia also significantly decreased endothelial sprouting in aortic explants isolated from TP508-injected mice compared to normoxic culture (2.3and 1.6-fold; fig. 3a, b), however, the area and cell migration of sprouting at day 5 of culture was similar to sprouting from explants isolated from control mice cultured in normoxia (fig. 3a). In contrast to normoxia, there was no significant difference in area of sprouting from aortic explants isolated from TP508-injected mice in response to VEGF stimulation when they were exposed to hypoxia (fig. 3a). However, we observed a significant increase in maximal migration of endothelial cells in response to VEGF stimulation from hypoxic explants isolated from TP508-treated mice compared to explants from control mice (at day 4 and 5 culture; fig. 3a). These results show that exposure of aortic explants to chronic hypoxia markedly attenuates basal and VEGF-stimulated angiogenesis. Moreover, explants from TP508-injected mice that were exposed to hypoxia had levels of sprouting similar to that seen in control mouse explants cultured in normoxia. Therefore, TP508 injection protected endothelial cells from hypoxic effects.

\section{Effect of TP508 Treatment on Expression of VEGF in HCAE Cells}

To gain a better understanding of how TP508 may exert its effects on endothelial cells in vivo, we examined effects of TP508 on HCAE cells in vitro. We first determined TP508 effects on VEGF expression since increased VEGF production might explain the in vivo effects of TP508. Real-time PCR experiments showed that under both normoxic and hypoxic $\left(1 \% \mathrm{O}_{2}\right)$ conditions, TP508 did not cause significant changes in VEGF mRNA expression levels during $24 \mathrm{~h}$ culture. Exposure of cells to hypoxia for $24 \mathrm{~h}$ increased VEGF mRNA expression $6.8 \pm$ 1.3 - and $7.5 \pm 1.8$-fold in control and TP508-treated cells, respectively (fig. $4 \mathrm{~b}$ ). These results showed that TP508 stimulation did not significantly affect the VEGF mRNA levels in normoxic or hypoxic cells. The concentrations of VEGF protein secreted into supernatants were also not significantly different between control and TP508-treated cells (data not shown). These results suggest that the in vivo effects of TP508 on endothelial sprouting are not likely to be due to TP508 changes in endothelial cell VEGF expression.

\section{Effects of Chronic Hypoxia on HCAE Cell Viability and NO Production}

To determine whether hypoxia-induced inhibition of endothelial sprouting from aortic explants was due to endothelial cell death, we exposed HCAE cells to hypoxia $\left(1 \% \mathrm{O}_{2}\right)$ for $48 \mathrm{~h}$. Hypoxic cells remained confluent and cell viability was similar to cells cultured in normoxia (fig 4a).

Production of NO by endothelial cells plays an important role in VEGF-stimulated angiogenesis in vivo [18] and in vitro [32]. Therefore, we measured the amount of NO produced by HCAE cells during $1 \mathrm{~h}$ incubation, $24 \mathrm{~h}$ after stimulation with TP508 or VEGF. As shown in figure 4c, TP508 and VEGF stimulated $115 \pm 33$ and $111 \pm$ $16 \mathrm{nM}$ of NO production, respectively, compared to $41 \pm$ $5 \mathrm{nM}$ of NO released from control cells (fig. 4c). Exposure of cells to hypoxia for $48 \mathrm{~h}$ resulted in attenuation of $\mathrm{NO}$ production from control ( $25 \pm 5 \mathrm{nM})$ and VEGF-stimulated cells $(40 \pm 17 \mathrm{nM})$. However, TP508-treatment of hypoxic cells increased NO production approximately 2 -fold relative to control normoxic cells ( $79 \pm 13$ vs. $41 \pm$ $5 \mathrm{nM}$; fig. 4c). Thus, hypoxia significantly inhibited VEGFstimulated NO production, but had no significant effect on NO production induced by TP508. TP508-induced increase in NO production in hypoxic endothelial cells correlates with TP508-stimulated endothelial sprouting from aortic explants exposed to chronic hypoxia. This suggests that in vivo TP508 may have a similar effect on NO production which serves to protect endothelial cells from hypoxia.

\section{Discussion}

The present studies were undertaken to determine the in vivo effect of thrombin peptide, TP508, on endothelial cell angiogenic responses under normoxic and hypoxic conditions. To address these questions we injected TP508 intravenously into mice and evaluated the effects of the peptide on angiogenesis using an aortic explant endothelial sprouting assay that mimics several stages of angiogenesis, including endothelial cell sprouting, proliferation, migration and tube-like structure formation [29]. Our results demonstrate that TP508 injection into mice $24 \mathrm{~h}$ prior to removal of aortas promotes endothelial sprouting and potentiates VEGF-stimulated endothelial sprouting. Exposure of aortic explants to chronic hypoxia markedly inhibited endothelial sprouting even after VEGF stimulation. However, aortic explants from TP508injected mice exposed to hypoxia showed increased sprouting similar that observed in aortic explants isolated from control mice cultured in normoxia.

Effective wound repair is dependent on the number of cellular processes including revascularization of injured 


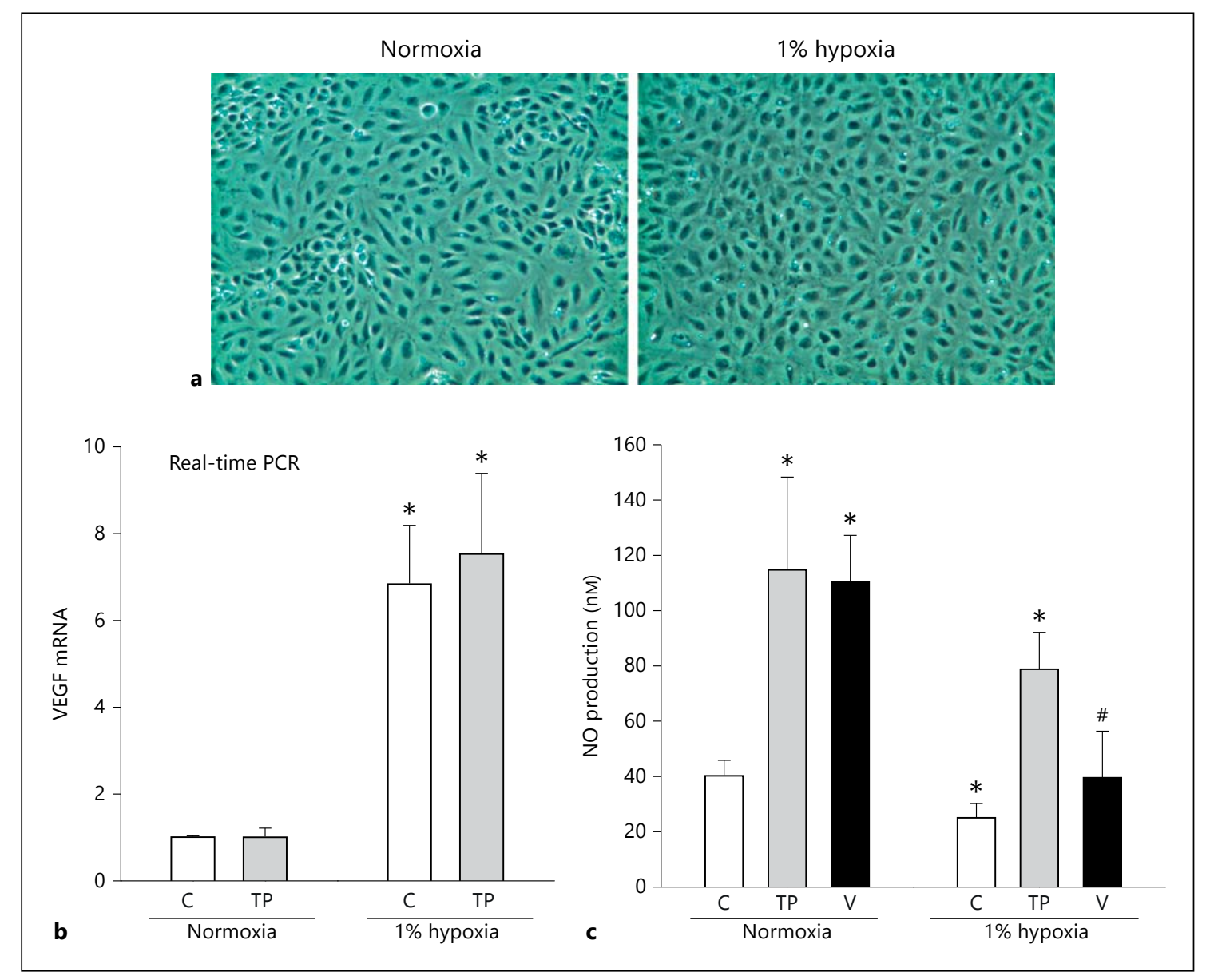

Fig. 4. Effects of TP508 and hypoxia on endothelial cell viability, expression of VEGF and NO production in vitro. a Confluent cultures of HCAE cells were maintained in normoxic or hypoxic $(1 \%$ $\mathrm{O}_{2}$ ) conditions for $48 \mathrm{~h}$. Representative phase-contrast images show viability of hypoxic cells comparable to normoxic cells (magnification $\times 100)$. b Real-time PCR analysis of human VEGF mRNA expression from control and TP508-treated $(50 \mu \mathrm{g} / \mathrm{ml})$ HCAE cells cultured in normoxic or hypoxic conditions for $24 \mathrm{~h}$. Data are expressed as a mean $\pm \mathrm{SD} ; \mathrm{n}=4 ;^{*} \mathrm{p}<0.01$ compared to

tissues [31]. TP508 has been previously shown to accelerate tissue revascularization and repair following tissue injury $[2,3,5,7,10]$. In a pig model of chronic myocardial ischemia, TP508 injection into the ischemic myocardium increased perfusion and restored myocardial function [24]. This treatment also increased NO-dependent vasodilation, expression of eNOS and NO production in arterioles isolated from ischemic heart regions [24]. We have shown that at the molecular level, TP508 stimulates rapid NO production in primary human endothelial cells [30] and prevents downregulation of eNOS expression in cells exposed to chronic hypoxia [24]. Intravenous injection of control in normoxia. c Confluent cultures of HCAE cells were maintained in normoxic or hypoxic $\left(1 \% \mathrm{O}_{2}\right)$ conditions for $24 \mathrm{~h}$. Next, cells were stimulated with TP508 $(50 \mu \mathrm{g} / \mathrm{ml})$ and VEGF $(50 \mathrm{ng} / \mathrm{ml})$ or vehicle control in the same conditions. After $24 \mathrm{~h}$, medium was replaced and all cells were cultured in normoxia. Supernatants were collected after $1 \mathrm{~h}$ and NO concentration was measured by NO analyzer. Data are expressed as a mean $\pm S D ; n=$ $4,{ }^{*} \mathrm{p}<0.01$ compared to control in normoxia, ${ }^{\#} \mathrm{p}<0.01$ compared to VEGF in normoxia. $\mathrm{C}=\mathrm{Control}$; $\mathrm{TP}=\mathrm{TP} 508 ; \mathrm{V}=\mathrm{VEGF}$.

TP508 has recently been shown to reduce the infarct area following acute myocardial ischemia-reperfusion injury in normal [25], hypercholesterolemic [26] and diabetic pigs [27]. This systemic effect of TP508 caused us to question whether systemic administration of TP508 could enhance angiogenesis or protect endothelial cells from ischemia.

The aortic sprouting assay is a well-established model for studying the effects of different factors on angiogenesis in vitro $[28,29]$. We used this model in a novel manner to determine in vivo effects of systemically injected TP508 on vascular endothelial cell responses to ex vivo 
angiogenic factors and hypoxia. To determine whether a single dose of TP508 injected into mice promotes angiogenesis, we isolated aortas from placebo control or TP508injected mice $24 \mathrm{~h}$ after injection and compared endothelial sprouting from aortic explants cultured on Matrigel Matrix. Our data show that TP508 injection significantly increased the area of endothelial sprouting and maximal migration of endothelial cells compared to aortic sprouting from control mouse explants.

VEGF is an endothelial-specific growth factor that is secreted by hypoxic cells at the site of injury to stimulate angiogenesis $[11,12]$. We therefore tested whether TP508 injection increases the responsiveness of endothelial cells to VEGF-stimulated angiogenesis. We found that VEGF stimulation of aortic explants isolated from TP508-injected mice showed significantly greater sprouting compared to VEGF-stimulated sprouting from control explants. These results demonstrate that TP508 injection not only promotes endothelial sprouting from aortic explants, but also potentiates responsiveness of aortic endothelial cells to VEGF.

Revascularization of chronic wounds and ischemic tissue is attenuated by endothelial dysfunction. Endothelial dysfunction induced by chronic hypoxia impairs angiogenesis in response to angiogenic factors [23]. In experimental animals, revascularization and recovery of blood flow to ischemic tissue is increased by administration of VEGF, but human clinical trials of therapeutic angiogenesis with VEGF were less successful than anticipated [20, $21,33]$. The differences between results in animals and clinical outcomes are postulated to involve different responsiveness of endothelial cells in young healthy animals used in laboratory studies compared to the endothelial cell responses in patients with chronic myocardial ischemia. Indeed, patients with coronary artery disease have endothelial dysfunction characterized by decreased expression of eNOS in endothelial cells $[34,35]$ which contributes to attenuation of NO production and defective NO-dependent vasodilation in atherosclerotic vessels [36]. In the present study, we also evaluated the effect of chronic hypoxia on angiogenesis using aortic explants. Our preliminary results showed that continued culture of aortic explants under hypoxia $\left(1 \% \mathrm{O}_{2}\right)$ completely inhibited endothelial sprouting, thus we exposed the aortic explants to hypoxia for 2 days followed by culture in normoxia. Exposure of aortic explants to hypoxia for 2 days inhibited endothelial cell sprouting and also markedly diminished VEGF-stimulated aortic sprouting compared to normoxia. These results are consistent with our previous report showing that chronic hypoxia decreases
VEGF-stimulated signaling and angiogenic responses of endothelial cells [23]. Interestingly, hypoxia had much less effect on endothelial sprouting from aortic explants isolated from TP508-injected mice. In fact, explants from TP508-injected mice that were exposed to hypoxia showed sprouting that was equivalent to that seen in normoxic explants from control mice. These results suggest that TP508 systemic administration protects endothelium from the effects of chronic hypoxia.

To determine potential molecular mechanisms of TP508 on endothelial cells that may explain how TP508 systemic administration potentiates VEGF-stimulated endothelial sprouting ex vivo, we performed in vitro studies using primary HCAE cells. A first question was whether the effects of TP508 might be related to TP508-induced production of VEGF. We found that in HCAE cells TP508 did not increase VEGF mRNA expression or VEGF protein production (data not shown). These results are consistent with a previous study showing that direct TP508 treatment of microvessels in culture increased sprout elongation, but did not increase VEGF mRNA expression [37]. Thus, it appears unlikely that in vivo effects of TP508 are mediated through stimulation of VEGF production.

We previously demonstrated that TP508 stimulates NO production in human endothelial cells by different mechanisms than VEGF [30]. Since NO production is required for VEGF-stimulated endothelial cells proliferation [15], migration [13,32] and tube formation [38], it seemed possible that TP508-stimulated NO production may contribute to enhancement of VEGF-induced endothelial sprouting from aortic explants. Our in vitro studies showed that TP508 and VEGF stimulated NO production in normoxic HCAE cells to nearly the same extent. In hypoxic cells, however, basal levels of NO production and VEGF-stimulated NO production were significantly decreased while TP508 still stimulated NO production by 2 - and 3 -fold over that of normoxic or hypoxic controls, respectively. Although it is difficult to compare effects observed in cells in culture with events that happen in vivo, these results suggest that production of NO induced by systemically injected TP508 may contribute to the protective effects on hypoxia-induced inhibition of endothelial sprouting from aortic explants. Moreover, previous studies demonstrated that wound healing [39] and angiogenesis is significantly impaired in eNOS-deficient mice and is not improved by administration of VEGF [40], suggesting that NO production by endothelial cells is essential for angiogenesis. If TP508 injected systemically is enhancing angiogenic responses to VEGF and protecting endothelial cells from hypoxia, 
one could ask whether this effect is specific for VEGF or whether a TP508 injection might also enhance responses to other angiogenic growth factors.

Preliminary experiments demonstrate that TP508 systemic administration also enhances endothelial sprouting stimulated by FGF (data not shown). That the systemic TP508 effect on endothelial sprouting is not limited to a single growth factor pathway is consistent with the broad range of effects of TP508 that could be mediated by activation of NO signaling in endothelial cells to promote revascularization.

Previous in vitro studies have shown that TP508 stimulates elongation of sprouts from cultured microvessel fragments [37] and that TP508 increases attachment of endothelial cells or chemotaxis $[41,42]$. In these in vitro studies, TP508 was added to the medium, where it could have a direct immediate effect on the cells [37], or was attached to the plates or inserts where it could interact with integrins expressed on endothelial cells through an RGD domain in the peptide to stimulate cell attachment and haptotactic migration [41]. However, in our current in vivo studies, TP508 was injected into animals $24 \mathrm{~h}$ before aortic fragments were isolated and placed in culture. Thus, the effects of TP508 occurred during the period in which TP508 was in contact with the cells in the animal and persisted through isolation and culture without additional TP508 treatment. Thus, our studies indicate that TP508 induces changes in the endothelial cells that persist after isolation to provide longer-term protection from hypoxia and increased responses to angiogenic factors.

These results are consistent with the hypothesis that TP508 represents a natural breakdown product of thrombin that is released from fibrin clots into circulation to stimulate tissue revascularization and repair [43, 44]. Studies are currently underway in our laboratory to identify the molecular mechanisms by which TP508 potentiates VEGF-stimulated intracellular signaling and endothelial cell functions in HCAE cells.

In summary, these results demonstrate for the first time that a single TP508 intravenous injection promotes angiogenic sprouting and potentiates VEGF-stimulated endothelial sprouting from aortic explants cultured under normoxic conditions. Exposure of aortic explants to hypoxia leads to inhibition of basal and VEGF-stimulated endothelial sprouting. Importantly, TP508 injection protects endothelial cells from the hypoxia-induced attenuation of endothelial sprouting. These results suggest a potential benefit of using a combination of systemic TP508 and local VEGF for treatment of chronic wounds and as a therapy for revascularization of ischemic tissues.

\section{Acknowledgements}

The authors thank Deborah Prusak and Dr. Thomas Wood of the UTMB Molecular Genomics Core Facility for real-time PCR analysis. The authors acknowledge research funding from The Texas Norman Hackerman Advanced Research Program and University of Texas Medical Branch Research Endowment Funds to D.H.C. Research reported in this manuscript was also supported in part by the National Institute of Allergy and Infectious Diseases of the National Institutes of Health (R43AI086135) and the National Cancer Institute (NCI/HHSN261201100035). Manuscript content is solely the responsibility of the authors and does not necessarily represent official views of the National Institutes of Health. Chrysalis BioTherapeutics Inc. of Galveston, Tex., and the University of Texas System own worldwide rights for commercialization of thrombin peptide TP508 (rusalatide acetate).

\section{References}

$>1$ Glenn KC, Frost GH, Bergmann JS, Carney DH: Synthetic peptides bind to high-affinity thrombin receptors and modulate thrombin mitogenesis. Peptide Res 1988;1:65-73.

$\checkmark 2$ Carney DH, Mann R, Redin WR, Pernia SD, Berry D, Heggers JP, Hayward PG, Robson MC, Christie J, Annable C, Fenton JWI, Glenn $\mathrm{KC}$ : Enhancement of incisional wound healing and neovascularization in normal rats by thrombin and synthetic thrombin receptoractivating peptides. J. Clin Invest 1992;89: 1469-1477.

3 Stiernberg J, Norfleet AM, Redin WR, Warner WS, Fritz RR, Carney DH: Acceleration of full-thickness wound healing in normal rats by the synthetic thrombin peptide, TP508. Wound Repair Regen 2000;8:204-215.
-4 Norfleet AM, Huang Y, Sower LE, Redin WR, Fritz RR, Carney DH: Thrombin peptide TP508 accelerates closure of dermal excisions in animal tissue with surgically induced ischemia. Wound Repair Regen 2000;8:517-529.

5 Wang H, Li X, Tomin E, Doty SB, Lane JM, Carney DH, Ryaby JT: Thrombin peptide (TP508) promotes fracture repair by up-regulating inflammatory mediators, early growth factors, and increasing angiogenesis. J Orthop Res 2005;23:671-679.

$\checkmark 6$ Sheller MR, Crowther RS, Kinney JH, Yang J, Di Jorio S, Breunig T, Carney DH, Ryaby JT: Repair of rabbit segmental defects with the thrombin peptide, TP508. J Orthop Res 2004; 22:1094-1099.
7 Li G, Ryaby JT, Carney DH, Wang H: Bone formation is enhanced by thrombin-related peptide TP508 during distraction osteogenesis. J Orthop Res 2005;23:196-202.

$>8$ Fife C, Mader JT, Stone J, Brill L, Satterfield K, Norfleet A, Zwernemann A, Ryaby JT, Carney DH: Thrombin peptide Chrysalin stimulates healing of diabetic foot ulcers in a placebocontrolled phase I/II study. Wound Repair Regen 2007;15:23-34.

$\checkmark 9$ Ryaby JT, Sheller MR, Levine BP, Bramlet DG, Ladd AL, Carney DH: Thrombin peptide TP508 stimulates cellular events leading to angiogenesis, revascularization, and repair of dermal and musculoskeletal tissues. J Bone Joint Surg Am 2006;88(suppl 3):132139.
TP508 Stimulates VEGF-Induced

Endothelial Cell Sprouting
J Vasc Res 2013;50:186-196 DOI: $10.1159 / 000348250$ 
$>10$ Norfleet AM, Bergmann JS, Carney DH: Thrombin peptide, TP508, stimulates angiogenic responses in animal models of dermal wound healing, in chick chorioallantoic membranes, and in cultured human aortic and microvascular endothelial cells. Gen Pharmacol 2000;35:249-254.

11 Ferrara N, Davis-Smyth T: The biology of vascular endothelial growth factor. Endocr Rev 1997;18:4-25.

12 Carmeliet P: Angiogenesis in health and disease. Nat Med 2003;9:653-660.

13 Dimmeler S, Dernbach E, Zeiher AM: Phosphorylation of the endothelial nitric oxide synthase at ser-1177 is required for VEGFinduced endothelial cell migration. FEBS Lett 2000;477:258-262.

14 Papapetropoulos A, Garcia-Cardena G, Madri JA, Sessa WC: Nitric oxide production contributes to the angiogenic properties of vascular endothelial growth factor in human endothelial cells. J Clin Invest 1997;100:31313139.

15 Parenti A, Morbidelli L, Cui XL, Douglas JG, Hood JD, Granger HJ, Ledda F, Ziche M: Nitric oxide is an upstream signal of vascular endothelial growth factor-induced extracellular signal-regulated kinase $1 / 2$ activation in postcapillary endothelium. J Biol Chem 1998;273: 4220-4226.

-16 Morbidelli L, Chang CH, Douglas JG, Granger HJ, Ledda F, Ziche M: Nitric oxide mediates mitogenic effect of VEGF on coronary venular endothelium. Am J Physiol 1996; 270:H411-H415.

-17 Wu HM, Huang Q, Yuan Y, Granger HJ: VEGF induces NO-dependent hyperpermeability in coronary venules. Am J Physiol 1996;271:H2735-H2739.

$\checkmark 18$ Ziche M, Morbidelli L, Choudhuri R, Zhang HT, Donnini S, Granger HJ, Bicknell R: Nitric oxide synthase lies downstream from vascular endothelial growth factor-induced but not basic fibroblast growth factor-induced angiogenesis. J Clin Invest 1997;99:2625-2634.

-19 Fukumura D, Gohongi T, Kadambi A, Izumi Y, Ang J, Yun CO, Buerk DG, Huang PL, Jain RK: Predominant role of endothelial nitric oxide synthase in vascular endothelial growth factor-induced angiogenesis and vascular permeability. Proc Natl Acad Sci USA 2001; 98:2604-2609.

20 Boodhwani M, Nakai Y, Mieno S, Voisine P, Bianchi C, Araujo EG, Feng J, Michael K, Li J, Sellke FW: Hypercholesterolemia impairs the myocardial angiogenic response in a swine model of chronic ischemia: role of endostatin and oxidative stress. Ann Thorac Surg 2006; 81:634-641.

21 Lekas M, Lekas P, Latter DA, Kutryk MB, Stewart DJ: Growth factor-induced therapeutic neovascularization for ischaemic vascular disease: time for a re-evaluation? Curr Opin Cardiol 2006;21:376-384.
22 Losordo DW, Dimmeler S: Therapeutic angiogenesis and vasculogenesis for ischemic disease. Part I: angiogenic cytokines. Circulation 2004; 109:2487-2491.

23 Olszewska-Pazdrak B, Hein TW, Olszewska $\mathrm{P}$, Carney DH: Chronic hypoxia attenuates VEGF signaling and angiogenic responses by downregulation of KDR in human endothelial cells. Am J Physiol Cell Physiol 2009; 296:C1162-C1170.

24 Fossum TW, Olszewska-Pazdrak B, Mertens MM, Makarski LA, Miller MW, Hein TW, Kuo L, Clubb F, Fuller GM, Carney DH: TP508 (Chrysalin) reverses endothelial dysfunction and increases perfusion and myocardial function in hearts with chronic ischemia. J Cardiovasc Pharmacol Ther 2008;13: 214-225.

25 Osipov RM, Bianchi C, Clements RT, Feng J, Liu Y, Xu SH, Robich MP, Wagstaff J, Sellke FW: Thrombin fragment (TP508) decreases myocardial infarction and apoptosis after ischemia reperfusion injury. Ann Thorac Surg 2009;87:786-793.

26 Osipov RM, Robich MP, Feng J, Clements RT, Liu Y, Glazer HP, Wagstaff J, Bianchi C, Sellke FW: The effect of thrombin fragment (TP508) on myocardial ischemia reperfusion injury in hypercholesterolemic pigs. J Appl Physiol 2009;106:1993-2001.

27 Chu LM, Osipov RM, Robich MP, Feng J, Sheller MR, Sellke FW: Effect of thrombin fragment (TP508) on myocardial ischemia reperfusion injury in a model of type 1 diabetes mellitus. Circulation 2010;122(suppl 11):S162S169.

28 Masson VV, Devy L, Grignet-Debrus C, Bernt S, Bajou K, Blacher S, Roland G, Chang Y, Fong T, Carmeliet P, Foidart JM, Noel A: Mouse aortic ring assay: a new approach of the molecular genetics of angiogenesis. Biol Proced Online 2002;4:24-31.

29 Lu J, Zhang K, Nam S, Anderson RA, Jove R, Wen W: Novel angiogenesis inhibitory activity in cinnamon extract blocks VEGFR2 kinase and downstream signaling. Carcinogenesis 2010;31:481-488.

30 Olszewska-Pazdrak B, Hart-Vantassell A, Carney DH: Thrombin peptide TP508 stimulates rapid nitric oxide production in human endothelial cells. J Vasc Res 2009;47:203-213.

31 Arnold F, West DC: Angiogenesis in wound healing. Pharmacol Ther 1991;52:407-422.

32 Murohara T, Witzenbichler B, Spyridopoulos I, Asahara T, Ding B, Sullivan A, Losordo DW, Isner JM: Role of endothelial nitric oxide synthase in endothelial cell migration. Arterioscler Thromb Vasc Biol 1999;19:11561161.

J Vasc Res 2013;50:186-196 DOI: $10.1159 / 000348250$
33 Losordo DW, Dimmeler S: Therapeutic angiogenesis and vasculogenesis for ischemic disease: part II: cell-based therapies. Circulation 2004;109:2692-2697.

34 Wilcox JN, Subramanian RR, Sundell CL, Tracey WR, Pollock JS, Harrison DG, Marsden PA: Expression of multiple isoforms of nitric oxide synthase in normal and atherosclerotic vessels. Arterioscler Thromb Vasc Biol 1997; 17:2479-2488.

35 Fukuchi M, Giaid A: Endothelial expression of endothelial nitric oxide synthase and endothelin-1 in human coronary artery disease: specific reference to underlying lesion. Lab Invest 1999;79:659-670.

36 Bossaller C, Habib GB, Yamamoto H, Williams C, Wells S, Henry PD: Impaired muscarinic endothelium-dependent relaxation and cyclic guanosine $5^{\prime}$-monophosphate formation in atherosclerotic human coronary artery and rabbit aorta. J Clin Invest 1987;79:170174.

37 Vartanian KB, Chen HY, Kennedy J, Beck SK, Ryaby JT, Wang H, Hoying JB: The non-proteolytically active thrombin peptide TP508 stimulates angiogenic sprouting. J Cell Physiol 2006;206:175-180.

38 Lin MI, Sessa WC: Vascular endothelial growth factor signaling to endothelial nitric oxide synthase: more than a FLeeTing moment. Circ Res 2006;99:666-668.

39 Lee PC, Salyapongse AN, Bragdon GA, Shears LL 2nd, Watkins SC, Edington HD, Billiar TR: Impaired wound healing and angiogenesis in eNOS-deficient mice. Am J Physiol 1999; 277:H1600-H1608.

40 Murohara T, Asahara T, Silver M, Bauters C, Masuda H, Kalka C, Kearney M, Chen D, Symes JF, Fishman MC, Huang PL, Isner JM: Nitric oxide synthase modulates angiogenesis in response to tissue ischemia. J Clin Invest 1998;101:2567-2578.

41 Tsopanoglou NE, Papaconstantinou ME, Flordellis CS, Maragoudakis ME: On the mode of action of thrombin-induced angiogenesis: thrombin peptide, TP508, mediates effects in endothelial cells via alphavbeta 3 integrin. Thromb Haemost 2004;92:846-857.

42 Li G, Cui Y, McIlmurray L, Allen WE, Wang $\mathrm{H}$ : rhBMP-2, rhVEGF(165), rhPTN and thrombin-related peptide, TP508 induce chemotaxis of human osteoblasts and microvascular endothelial cells. J Orthop Res 2005;23: 680-685.

43 Carney DH, Olszewska-Pazdrak B: Could rusalatide acetate be the future drug of choice for diabetic foot ulcers and fracture repair? Expert Opin Pharmacother 2008;9:2717-2726.

44 Olszewska-Pazdrak B, Bergmann JS, Fuller GM, Carney DH: The role of thrombin and thrombin peptides in wound healing and tissue repair; in Maragoudakis ME, Tsopanoglou NE (eds): Thrombin Physiology and Disease,. New York, Springer, 2009, pp 115-132. 